\title{
Effects of Chloramphenicol, Clofibric Acid, Acetyl Salicylic Acid, Nonylphenol and Bisphenol on the Protein Profile and Ultrastructure of Marine Macroalgae Pterocladia capillacea and Ulva lactuca
}

\author{
Soad M. Mohy El-Din*, Nadia H. Noaman and Seham H. Zaky \\ Botany and Microbiology Department, Faculty of Science, \\ Alexandria University, Egypt.
}

\begin{abstract}
RGANIC pollution is prominent environmental issue concerning water pollution in the world. It is important to reveal the effects of organic pollutants on algal growth and toxin production for assessing ecological risk of organic pollution. Polyacrylamide gel electrophoresis (SDS PAGE) was tested as analytical tool for the isolation and identification of protein. The treatment of Pterocladia capillacea and Ulva lactuca with chloramphenicol, clofibric acid, acetyl salicylic acid, nonylphenol and bisphenol stimulated the synthesis of (three and eight) high molecular masses polypeptides, respectively, (five and six) low molecular masses polypeptides, respectively. On the other hand, inhibition of 31.51 and $12.30 \mathrm{KDa}$ protein in Pterocladia capillacea and Ulva lactuca after the same treatments, respectively. Examination of electron micrographs of Pterocladia capillacea and Ulva lactuca pharmaceutical treated cells reflected damages in chloroplast structures, which manifested by change in the thylakoid number, rupture and dissolving of thylakoid membranes. In addition, disintegration of the chloroplast in some parts, appearance of necrotic areas, deformation in the cell wall as well as deformation in the morphology of the cells are clear.
\end{abstract}

Keywords: Macroalgae, Pharmaceuticals, Protein pattern, Electrophoresis, Ultrastructure.

In recent years, the growing and uncontrolled use of drugs in farming, aquaculture and human health, in addition to improper disposal of expired, medicines has led to concern about their occurrence in the environment. Not surprising, many monitoring studies have detected low concentrations of a wide range of pharmacologically active substances, including hormones, steroids, antibiotics, anti-inflammatory drugs and diuretics in soils, surface water, and ground water ( Zuccato et al.,2000; Jones et al.,2002 and Koplin et al.,2002). Pharmaceuticals and their metabolic products reach the sewage system through wastewater, but often are not completely removed by sewage treatment plants (Stumpf et al., 1999). Stumpf et al. (1996) identified diclofenac $\left(\leq 1.59 \mu \mathrm{L}^{-1}\right)$, ibuprofen $\left(\leq 3.35 \mu \mathrm{L}^{-1}\right)$ and acetyl salicylic acid (ASA) $\left(\leq 1.51 \mu \mathrm{L}^{-1}\right)$ in sewage, and lower concentrations $\left(0.01-0.5 \mu \mathrm{gL}^{-1}\right)$, diclofenac and ibuprofen could be detected even in drinking water. ( Ternes et al.,1998) reported concentrations of diclofenac, ibuprofen, ASA and other compounds, some $>1 \mu \mathrm{gL}^{-1}$ in waste water

*Corresponding Author: Soad M. Mohy El-Din, (E-mail: dr.soad_mohi@hotmail.com) 
treatment plants and again lower concentration in surface water. Thus, pharmaceuticals pollutants have become a rapidly emerging area of concern in the field of ecotoxicology, causing them to be viewed as a new class of priority pollutants (Zuccato et al.,2000).

With the escalation of industrial processes and the expansion of urban population, a vast amount of organic pollutants in industrial waste, residue pesticide and sewage have been released into the environment. Many of the organic pollutants are persistent organic pollutants (POPs) and endocrine disruptors with potential of persistence, half-volatile and bioaccumulation in the environment. These pollutants show potential toxicity, carcinogenicity and/or mutagenicity to human, causing great concerns to the society (Wang et al.,2007 and Gao \& Yan 2012).

Rath and Adhikary (2007) demonstrated that the exposure of estuarine cyanobacterium Lyngbya aesturii to UV radiation resulted in differential expression of cellular proteins. Bhargava et al.(2006) expressed copper-induced changes in protein profiling of Anabaena doliolum subjected to short-and longterm treatments. Sodium dodecyl sulphate polyacrylamide gel electrophoresis analyses of the total protein profile of Anabaena doliolum showed a linear decrease in protein content with increasing UV exposure time (Sinha et al.,1996).

Many authors have used the ultrastructure changes of the algal cells observed in their transmission electron micrograph as a tool to express the toxicity induced by heavy metals, pesticides, organic pollutants and pharmaceuticals especially antibiotics ( Mooney \& Patching 1998 and Kovacevic et al.,2001) . In this paper, we studied the effect of environmental and synthetic pollutants as different pharmaceuticals on the protein profile and ultrastructure of red alga Pterocladia capillacea and green alga Ulva lactuca..

\section{Materials and methods}

\section{Tested algae}

Pterocladia capillace (c. Agardh) is a genus of red macroalgae, class Florideophyceae and order Gelidiales. Ulva lactua linneals (Gmel) Born is a genus of green macroalgae, class Ulvophyceae and order Ulvales. Healthy samples of the algae were collected from about one and half meter depth of Mediterranean Sea shore of Alexandria, Abu-Qir in 2014

\section{Chemicals}

All chemicals reagents employed in this study were purchased from sigma Aldrich, companies (Table1). The concentration of pharmaceutical were quantified using HPLC device equipped with UV-light spectrophotometer or fluorescence detector. The instrument was initially calibrated before each use with standard solution for each compound. Conditions of HPLC assay for acetyl salicylic acid by Akay et al. (2008), chloramphenicol by Barata et al. (2005), 
clofibric acid by Lau-Cam et al. (2006), nonylphenol by Wang and Xie (2007) and bisphenol by Gattulo et al. (2012).

TABLE 1. The chemical structure and IUPAC name of different pharmaceuticals used in this study.

\begin{tabular}{|c|c|c|}
\hline $\begin{array}{c}\text { Pharmaceutical } \\
\text { name }\end{array}$ & Chemical structure & IUPAC Name \\
\hline Chloramphenicol & & $\begin{array}{c}\text { 2,2-dichloro-N-[1,3- } \\
\text { dihydroxy-1- } \\
\text { (4nitrophenyl)propan-2-yl] } \\
\text { acetamide }\end{array}$ \\
\hline Acetyl salicylic acid & & 2-acetoxybenzoic acid \\
\hline Clofibric acid & & $\begin{array}{l}\text { 2-(4-Chlorophenoxy)-2- } \\
\text { methylpropanoic acid }\end{array}$ \\
\hline Nonylphenol & & $\begin{array}{l}\text { 4-(2,4-dimethylheptan- } \\
\text { 3yl)phenol }\end{array}$ \\
\hline Bisphenol & $\mathrm{CH}_{3}$ & $\begin{array}{l}\text { 4,4'-(propane-2,2- } \\
\text { diyl)diphenol }\end{array}$ \\
\hline
\end{tabular}

\section{Experimental design}

Pterocladia copillacea and Ulva lactuca were grown in 500 Erlenmeyer flasks by mixing $1 \mathrm{gm}$ of fresh algal biomass with $100 \mathrm{ml}$ of pharmaceutical solution of specific concentration. The different concentrations of pharmaceuticals were prepared viz, 5, 10, 15, 20, 25, 30, 35 and 40mg/L were used in case of algae tolerance experiments. The compound concentration prepared by adequate dilution of its stock solution using seawater. The stocks of acetyl salicylic acid, clofibric acid, nonylphenol and bisphenol were prepared by dissolving $1000 \mathrm{mg}$ of each pharmaceutical compound in one liter of methanol while for chloramphenicol was prepared by dissolving $1000 \mathrm{mg}$ of antibiotic in one liter of deionized distilled water. The biosorption experiment concentrations of acetyl salicylic acid $(20 \mathrm{mg} / \mathrm{L}$ for $P$. capillacea and $20 \mathrm{mg} / \mathrm{L}$ for $U$. lactuca), chloramphenicol $(25 \mathrm{mg} / \mathrm{L}$ for $P$. capillacea and $15 \mathrm{mg} / \mathrm{L}$ for $U$. lactuca), clofibric acid $(5 \mathrm{mg} / \mathrm{L}$ for $P$. capillacea and $35 \mathrm{mg} / \mathrm{L}$ for $U$. lactuca), nonylphenol $(5 \mathrm{mg} / \mathrm{L}$ for $P$. capillacea and $20 \mathrm{mg} / \mathrm{L}$ for $U$. lactuca ) and bisphenol $(10 \mathrm{mg} / \mathrm{L}$ for $P$. capillacea and $20 \mathrm{mg} / \mathrm{L}$ for $U$. lactuca). The maximum biosorption was achieved by both algae after $12 \mathrm{hr}$. Moreover, increasing contact time from 12 up to $36 \mathrm{hr}$ resulted in a slight decrease in biosorption of all pharmaceuticals. 
The experiment was performed at natural light photoperiod (16h. light/8h. dark) and room temperature $\left(29 \pm 2^{\circ} \mathrm{c}\right)$ with three replicas. The control was carried out by using the algal biomass in seawater (without addition of pharmaceutical compounds). The fresh biological materials were subjected to protein profile and transmission electron microscope.

Protein pattern analysis

In this study, protein profile was analyzed by sodium dodecyl sulphate polyacrylamide gel electrophoresis (SDS-PAGE) according to Laemmli (1970), by applying phast-system apparatus.

\section{Protein samples preparation}

The samples were homogenized with $5 \mathrm{ml}$ of tris- $\mathrm{HCl}$ buffer, $\mathrm{pH}$ 7.2. The homogenate solutions were centrifuged at $6.000 \mathrm{rpm}$ for $10 \mathrm{~min}$. the clear supernatant immediately examined. Samples were applied to the slab gel along with molecular weight marker (BioRad, pertained-SDS markers). Electrophoresis was carried out at a constant voltage 150 volts for about two hr. The gel was then stained with Coomassie Brilliant Blue R-250 (0.06\% Coomassie Brilliant Blue R-250 in 50\% methanol, 10\% acetic acid) for one hour with gentle agitation at room temperature.

\section{Transmission electron microscope}

Pterocladia capillacea and Ulva lactuca biomasses prepared for transmission Electron Microscope (Ziess-EM 10) examination using the method described by (Mercer and Birbeck, 1966).

\section{Results}

Changes in Polypeptide Pattern of Pterocladia capillacea under different treatments

Synthesis of an induced new set of proteins and at the same time, decline of one protein were observed (Plate 1). After $12 \mathrm{hr}$ of incubation, in different treatments, algal masses showed fewer higher molecular weight bands of 51.43, 73.57 and $98.42 \mathrm{KDa}$, which were absent in the control. In addition, several lower molecular mass polypeptides of 34.37, 25.70, 21.97, 21.01 and 17.96 KDa were newly produced in the treated algal samples. It was evident from the results that there is no difference in the band number between the different treatments. It is clear that the band intensity was less in the fresh algal masses grown in medium containing chloramphenicol in comparison with clofibric acid, acetyl salicylic acid, bisphenol or nonylphenol treated algal samples. It can also be observed that a protein band of $31.51 \mathrm{KDa}$ was completely eliminated after all treatments, which was originally detected in the control. 


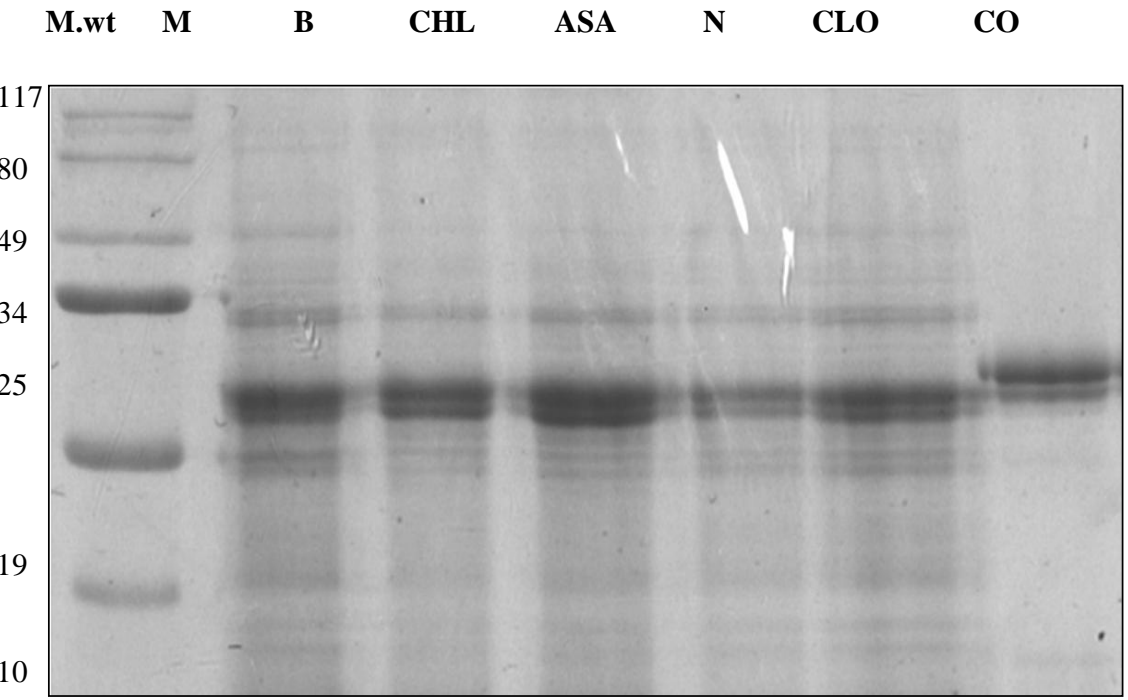

Plate 1. Effects of five pharmaceuticals on polypeptide patterns of total proteins from Pterocladia capillacea as analyzed on SDS-PAGE. Lanes from right to left represent protein extracted from control (CO), Clofibric acid (CIO), nonylphenol (N), acetyl salicylic acid (ASA), chloramphenicol (CHL) and bisphenol (B) treated Pterocladia capillacea after 12 hours of treatment, respectively, and lane $M$ represents the molecular weight marker. Equal amounts of protein were loaded into each well.

Changes in Polypeptide Pattern of Ulva lactuca under different treatments

Protein profiling by SDS-PAGE revealed distinct bands for U. lactuca (Plate 2), indicating that exposure to chloramphenicol or bisphenol induced synthesis of a new set of polypeptides of $88.104,79.43,52.48,45.70,39.81,26.30$ and 18.62 $\mathrm{KDa}$, which were completely absent in the control. However, these bands were denser in chloramphenicol-treated samples as compared to bisphenol. Five novel polypeptides of higher molecular masses of 104.71, 94.40, 83.17, 79.43 and $56.23 \mathrm{KDa}$ were identified in cells grown in sea water amended with one of the three compounds (clofibric acid or nonylphenol or acetyl salicylic acid). In addition, two newly-synthesized lower molecular masses proteins (45.70 and $39.81 \mathrm{KDa}$ ) were also visualized after $12 \mathrm{hr}$ of exposure to any of the three compounds.

\section{Ultrastructure}

Under normal conditions, subcellular components of Pterocladia capillacea showed the presence of well arranged thylakoid in a typical chloroplast and well defined mitochondria ( Fig.1). Meanwhile, the Ulva lactuca in (Fig.2) indicated the arrangement of the cell components, the presence of well defined nucleus, regular cell wall and two large pyrenoids with a prominent starchy sheath inside the intact chloroplast. 


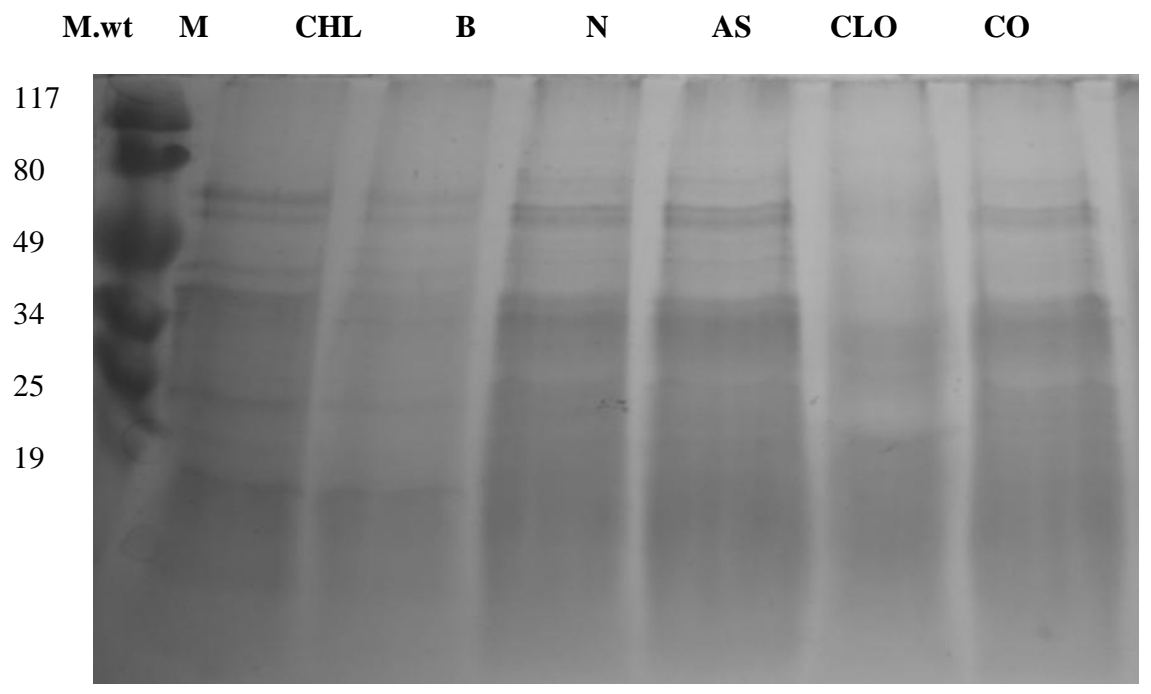

Plate 2. Effects of five pharmaceuticals on polypeptide patterns of total proteins from Ulva lactuca as analyzed on SDS-PAGE. Lanes from right to left represent proteins extracted from control (CO), clofibric acid (CLO), acetyl salicylic acid (ASA), nonylphenol (N), bisphenol (B) and chloramphenicol (CHL) treated $U$. lactuca after 12 hours of treatment, respectively, and lane $M$ represents the molecular weight marker. Equal amounts of proteins were loaded into each well.

After the treatment with acetyl salicylic acid $(20 \mathrm{mg} / \mathrm{L})$, Pterocladia electronmicrographs showed the appearance of large vacuolar system, lipid droplets identification, irregularity of cell wall, aggregation of unclear dark cellular inclusions (Figs. 3-6). In addition, the chloroplast membranes (thylakoids) began to dissolve in some cells (Figs. 5 and 6). In the same trend, acetyl salicylic acid $(20 \mathrm{mg} / \mathrm{L})$ treatment induced more or less similar ultrastructure alternations in Ulva as represented by Fig. 7 and 8, which include visualization of irregular cell wall, formation of vacuoles and appearance of numerous dark deposits within the cytoplasm . In addition, starch grains appeared inside chloroplast. Moreover, the chloroplast began to disintegrate in some parts in longitudinal fashion or in some cells, necrotic areas take place.

Examination of electron micrographs after immersing Pterocladia fresh algal biomass in $25 \mathrm{mg} / \mathrm{L}$ chloramphenicol for a time period extended to $12 \mathrm{hr}$ revealed the severe deformation of cell wall, accumulation of huge starch grains inside chloroplast (Fig. 9 and 10), appearance of dark unclear cellular components and formation of large vacuoles containing net-like dark deposits. Some of these ultrastructural changes could be also detected in chloramphenicol-treated Ulva cells (Fig.11) including: the deformation in cell wall and formation of vacuoles but it can be noticed that vacuolar system in chloramphenicol-treated Ulva was more pronounced and included several vacuole compartments. The chloroplast began to disintegrate in some parts, which appear faint in color than surrounding areas.

Egypt. J. Bot., 56, No. 1 (2016) 
Exposure to clofibric acid $(5 \mathrm{mg} / \mathrm{L})$ resulted in dramatic damage in Pterocladia fine structures that could be examined in Fig. 12 and 13. The clofibric -treated cells displayed complete and partial loss of cell wall, complete disorganization of cellular inclusions, accumulation of several moderate sized starch grains, complete damage of thylakoidal membranes, appearance of lumens within chloroplast, breaking down of plastid envelope, rupture of plasma lemma, and appearance of numerous small vesicles. While Ulva cells exhibited less damage in its subcellular components under clofibric stress $(35 \mathrm{mg} / \mathrm{L})$ as shown in Fig. 14 and 15, which demonstrated the appearance of vacuoles, precipitation of clofibric in black spots, and sieve-like necrotic areas appeared in some parts of the chloroplast. However, the nucleus remained unaffected.

Transmission electron microscopy, some ultra-structural modifications were examined in nonylphenol-treated Pterocladia. Such as disorganization of the chloroplast membranes, swelling up of the grana lamellae, deformation in cell wall and presence of oil droplets (Fig. 16 and 17 ) beside some other induced changes like dilation of the inner layers of cell wall and detachment of phycobilisomes from the thylakoidal membranes. Transmission electron microscopy of nonylphenol-treated Ulva reflected severe changes in the chloroplast and cell wall (Fig. 18, 19 and 20) as the thylakoidal membranes appeared loosely disarranged and number of grana lamellae increased, the chloroplast envelope broken in some regions and large several whorl membranous structures were identified inside the chloroplast. The whole cell volume decreased and deformed cell wall was noticed, which became thin in some parts between the neighboring cells.

Bisphenol stress $(10 \mathrm{mg} / \mathrm{L})$ resulted in destructive changes in sub-cellular components of Pterocladia especially chloroplast, these changes were shown in Fig 21 and 22 and they comprised partial to complete destruction of thylakoidal membranes, breaking down of chloroplast envelope, disturbance of the fine structures, rupture of plasma lemma and beginning of cell wall lyses. Meanwhile, treating Ulva cells with bisphenol $(20 \mathrm{mg} / \mathrm{L})$ induced vacuoles compartments to be formed which surrounded by black thick membranes, dark deposits to be aggregated within the cell and grana layers to be dissolved and disarranged. In addition, the chloroplast envelope was broken and lumens were formed between grana lamellae (Fig. 23 and 24).

\section{Discussion}

In the present investigation, the treatment of $P$. capillacea with chloramphenicol, clofibric acid and acetyl salicylic acid stimulated the synthesis of three high molecular masses polypeptides and five low molecular masses proteins. Meanwhile, the same treatments stress in U. lactuca was associated with the appearance of six low molecular weight bands and eight high molecular weight bands. The change in protein synthesis in seaweeds grown under pharmaceuticals stress could be due to changes in gene expression that induce the synthesis of new types of RNA, which become translated into new proteins called growth-limiting 
protein required for growth and survival (Weber and Jung. 2002). Our results tend to agree with Rajendran et al.(2007) who reported that the production of novel proteins or the increased production of already existing proteins, which are only produced under stress conditions due to stress response.

On the other hand, a successive decrease in the protein profiling pattern was observed in the present investigation, which was confirmed by the inhibition of $31.51 \mathrm{KDa}$ protein in $P$. capillcea under the three pharmaceutical treatments (chloramphenicol, clofibric acid and acetyl salicylic acid). In addition, to the 12.30 KDa polypeptide elimination in $U$. lactuca after clofibric acid and acetyl salicylic acid treatments. This could be the result of toxic action of the tested pharmaceuticals on the enzymatic reactions responsible for protein biosynthesis. These findings are consistent with the results of the previous publications (Yoshida et al., 2006). They reported that some environmental conditions affect the protein profiles expressed under stress. For instance, sodium dodecyl sulphate protein profile of the UV irradiated Lyngbya cells showed repression of 20 and 22 KDa proteins (Rath and Adhikary, 2007).

Examination of electron micrographs of $P$. capillcaea and $U$. lactuca pharmaceutical treated cells reflected damages in chloroplast structures with different degrees, which could be clearly observed. These damages were manifested by increase in the number of thylakoids, loose disarrangement of the grana lamellae, disintegration of the chloroplast in some parts, destruction of chloroplast envelope, appearance of necrotic areas and presence of whorl membranous structures inside the chloroplast. These results are greatly consistent with those of $\mathrm{Yu}$ et al. (2007) who demonstrated a change in the thylakoid number, even rupture and dissolving of the thylakoid membranes of the Gracilaria lemaneiformis chloroplast, after treatment with dimethyl phthalate, in addition to the disappearance of the chloroplast envelope. A similar observation were reported for the effect of chloramphenicol and spectoinomycin on the Ochromonas danica (Smith- johanson \& Gibbs, 1972 and Smith- johanson et al ., 1980). The similar effects of heavy metals $\left(\mathrm{Pb}^{2+}\right.$ and $\left.\mathrm{Cd}^{2+}\right)$ on the ultrastructure and pigment contents of the unicellular cyanobacterium Synechocystis sp. (Arunakumara and Zhang Xuecheng, 2009 and Shanab et al., 2012). In addition, $\mathrm{Cd}^{2+}$ and $\mathrm{Pb}^{2+}$ also caused the disintegration and disorganization of thylakoid membranes and chloroplast membranes in photosynthetic organisms such as plants, cyanobacteria, micro- and macroalgae (Rangsayatorn et al., 2002 and Gao \& yan, 2012).

Transmission electron microscopy also revealed deformation in the cell wall. This notice go parallel with that of Kovacevic et al. (2001) who found that some algal cells of Chlorella had their cell wall damaged after the treatment with chloramphenicol. Scenedesmus obliquus showed increased cell volume, as well as deformations in individual cell division and in the morphology of colony cells, such as herringbone trouser chain and astral- shaped deformations as consequences of cypermethrin toxicity (Xiong et al., 2002 and Kaplon, 2013).

Egypt. J. Bot., 56, No. 1 (2016) 


\section{Conclusions}

We can conclude that the Pterocladia capillacea and Ulva lactuca are more sensitive to harmful effect of the drugs. In addition, pharmaceuticals in surface waters can be removed. There is a potential risk for non-target organisms associated with low levels of pharmaceuticals in surface waters.

Pharmaceuticals such as acetyl salicylic acid, chloramphenicol and clofibric acid and the endocrine disruptor substances as nonylphenol and bisphenol can reach surface water and although they can be degraded in the environment by biotic or abiotic process, it is assumed that drugs could act as persistent compounds simply because of their continual infusion into aquatic media. Therefore, safe ways of discarding drug residues should be developed in order to protect the aquatic fauna. More drug toxicity tests must carried out on different levels of aquatic organisms to be able to predict their impact on our aquatic environment. The removal of these compounds from aqueous environments or its reduction to non-toxic levels is a priority goal in water quality management.
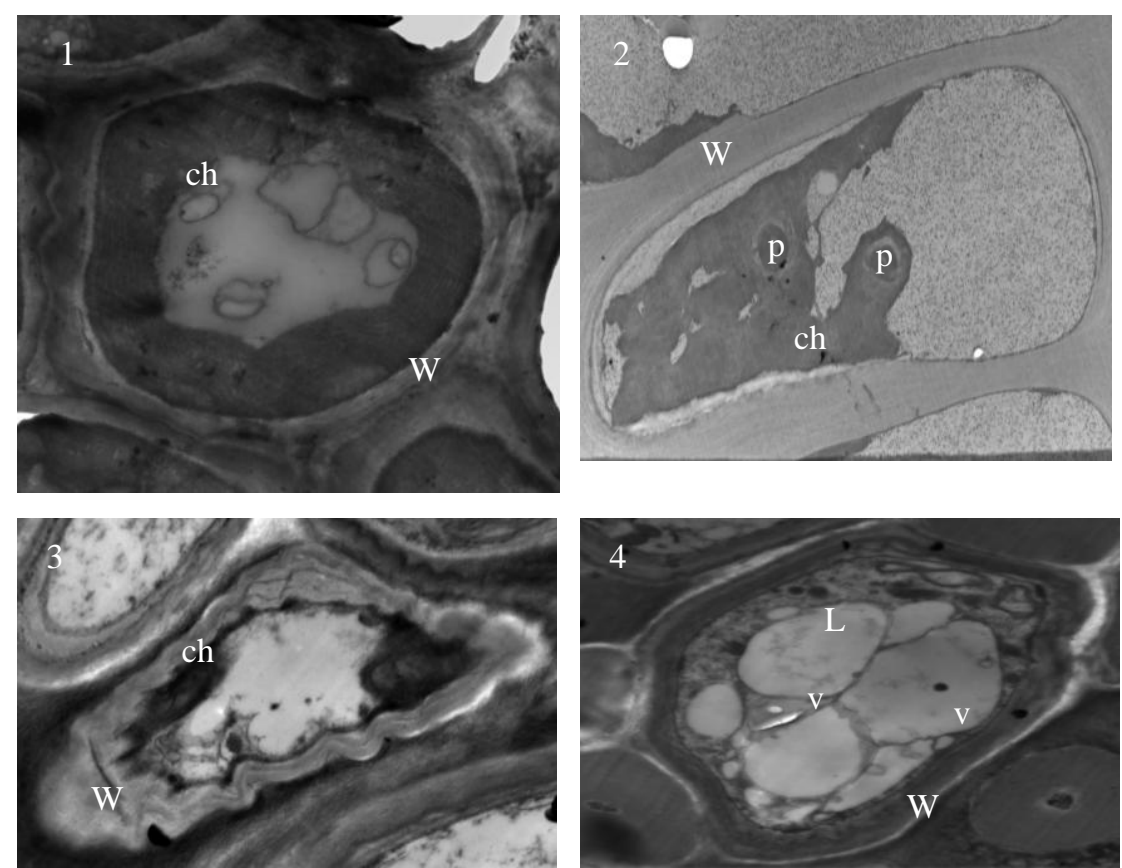

Fig.1-4. Electron micrographs of Pterocladia capillacea and Ulva lactuca before and after exposure to different treatments. Fig.1. Normal Pterocladia before treatment, Fig. 2. Normal Ulva before treatment, Fig. 3\&4 Pterocladia after exposure to acetyl salicylic acid. In the sections showing the cell wall (W),the chloroplast $(\mathrm{Ch})$, the pyrenoid $(\mathrm{P})$, the lipid droplets $(\mathrm{L})$, the vacuole $(\mathrm{V})$.

Egypt. J. Bot., 56, No. 1 (2016) 

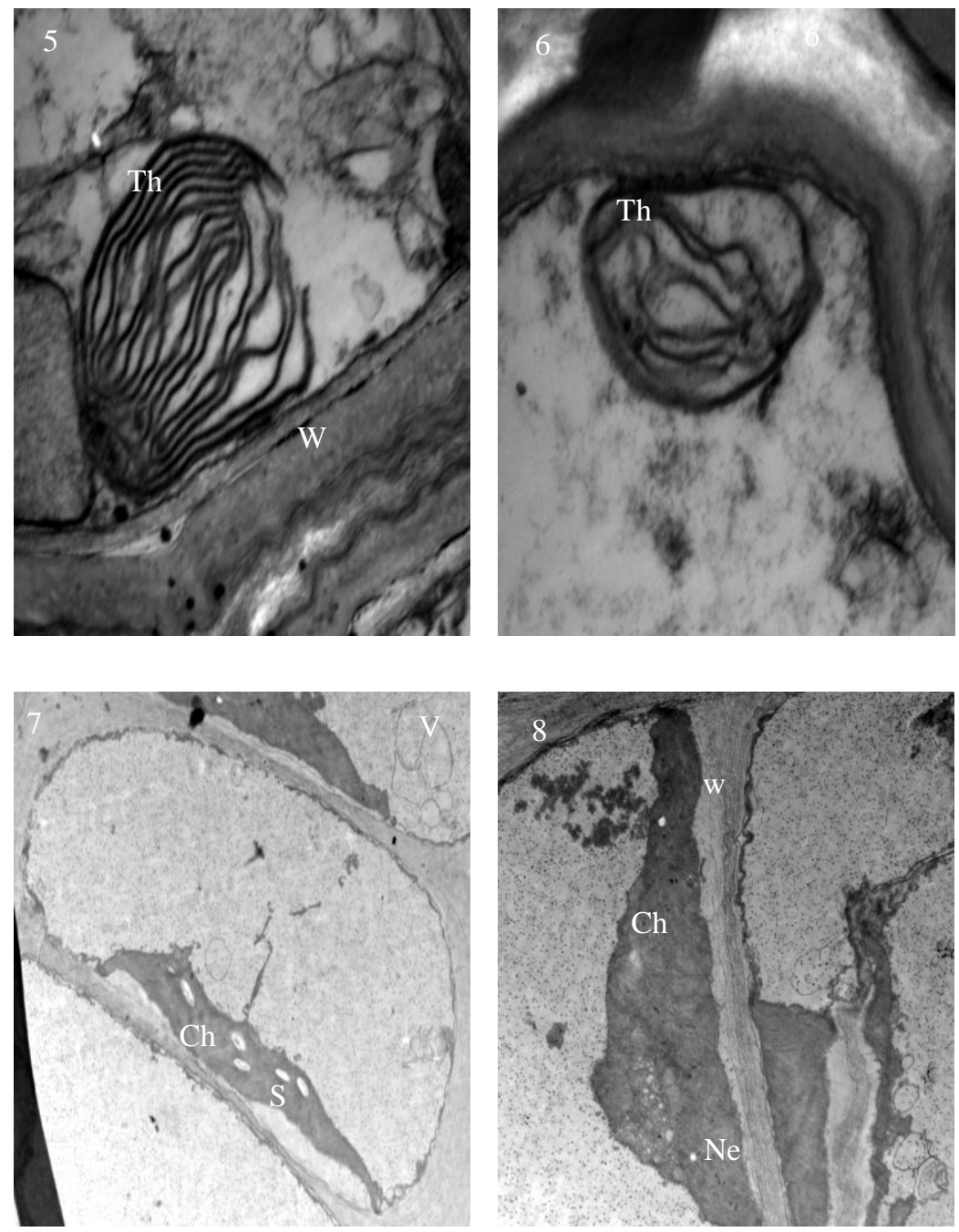

Fig.5-8. Electron micrographs of Pterocladia capillacea and Ulva lactuca after exposure to different treatments. Fig. 5\&6. Details chloroplast (thylakoids), of Pterocladia after exposure to acetyl salicylic acid, Fig. 7\&8.Ulva after exposure to acetyl salicylic acid. In the sections showing the cell wall $(\mathrm{W})$, the chloroplast $(\mathrm{Ch})$, the pyrenoid $(\mathbf{P})$, the lipid droplets $(\mathrm{L})$, the vacuole $(\mathrm{V})$, the thylakoids of chloroplast $(\mathrm{Th})$, the starch grain $(\mathrm{S})$ and the necrosis $(\mathrm{Ne})$.

Egypt. J. Bot., 56, No. 1 (2016) 

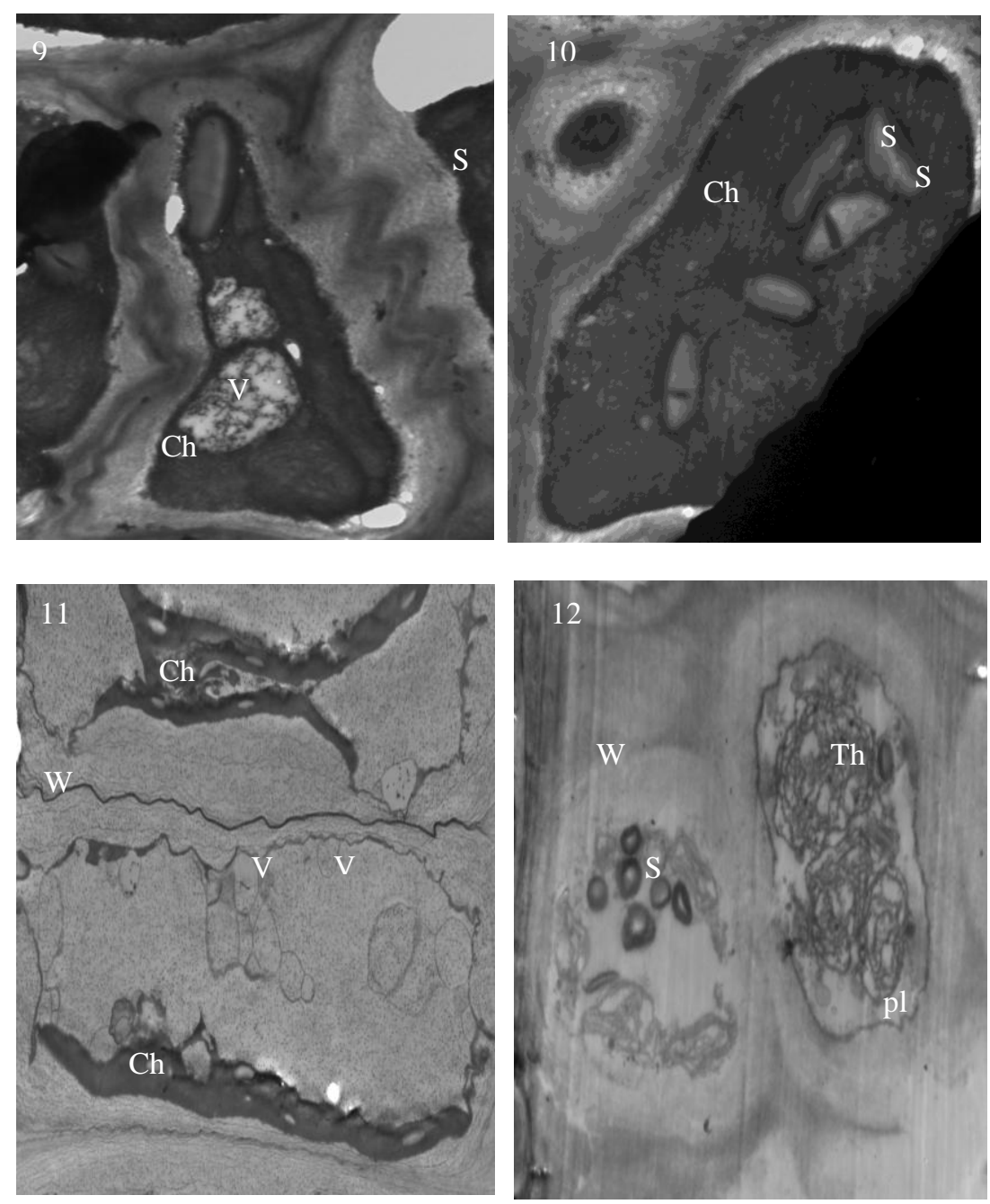

Fig. 9-12. Electron micrographs of $\boldsymbol{P}$. capillacea and $\boldsymbol{U}$. lactuca after exposure to different treatments. Fig. 9. Pterocladia after exposure to chloramphenicol. Fig.10. Details of chloroplast of Pterocladia after exposed to chloramphenicol. Fig.11. Ulva after exposure to chloramphenicol. Fig.12. Pterocladia after exposure to clofibric acid. In the sections showing the starch grain $(\mathrm{S})$, the chloroplast $(\mathrm{Ch})$, the cell wall $(\mathrm{W})$, the vacuole $(\mathrm{V})$, the thylakoids of chloroplast $(\mathrm{Th})$ and the plasma lemma (PL). 

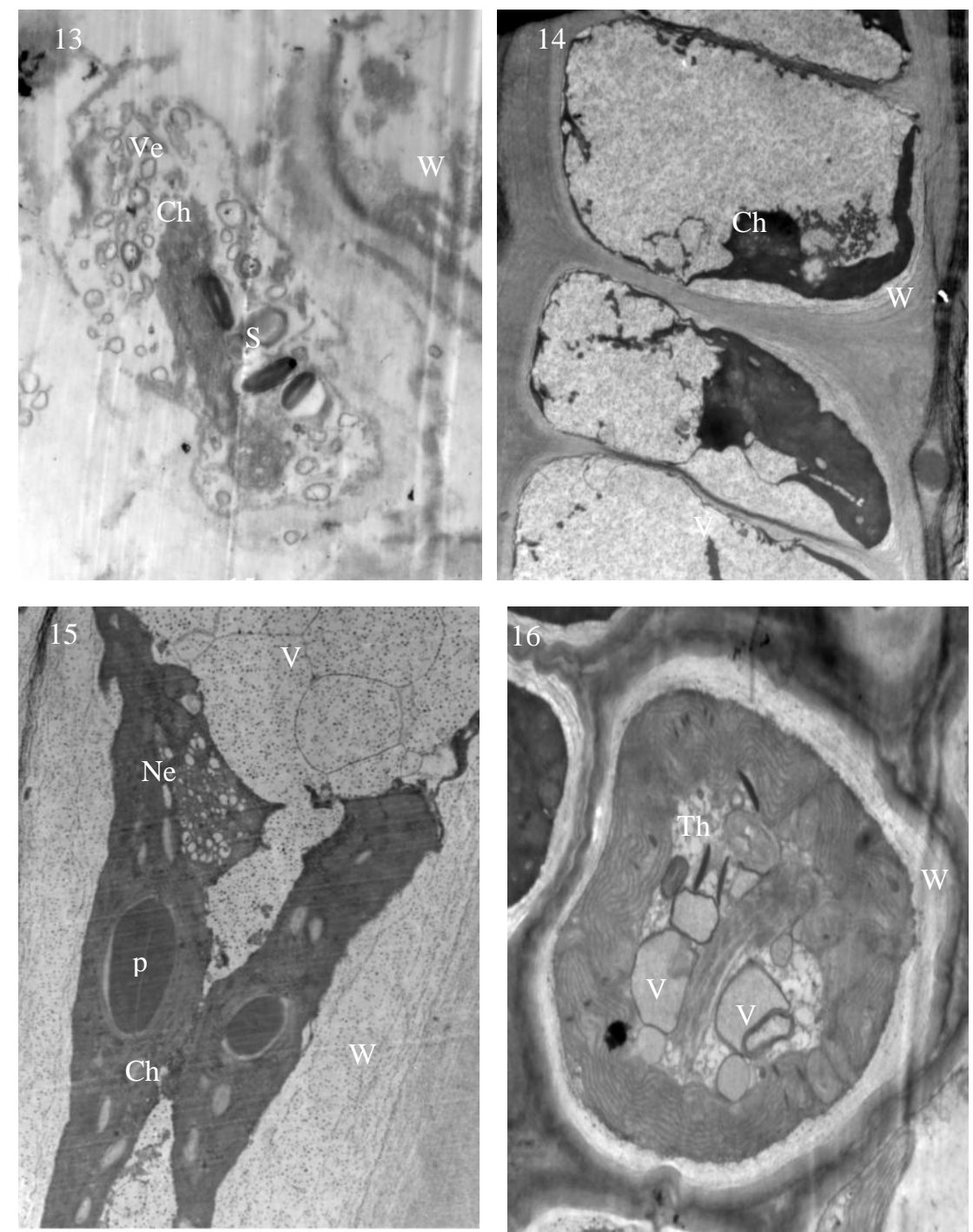

Fig. 13-16. Electron micrographs of $P$. capillacea and $U$. lactuca after exposure to different treatments. Fig.13. Pterocladia after exposure to clofibric acid. Fig.14\&15.Ulva after exposure to clofibric acid.Fig.16. Pterocladia after exposure to nonylphenol. In the sections showing the chloroplast $(\mathrm{Ch})$, The cell wall $(\mathrm{W})$, the vacuole $(\mathrm{V})$, the thylakoids of chloroplast $(\mathrm{Th})$, the vesicle (Ve), The necrosis $(\mathrm{Ne})$ and the pyrenoid $(\mathrm{P})$. 

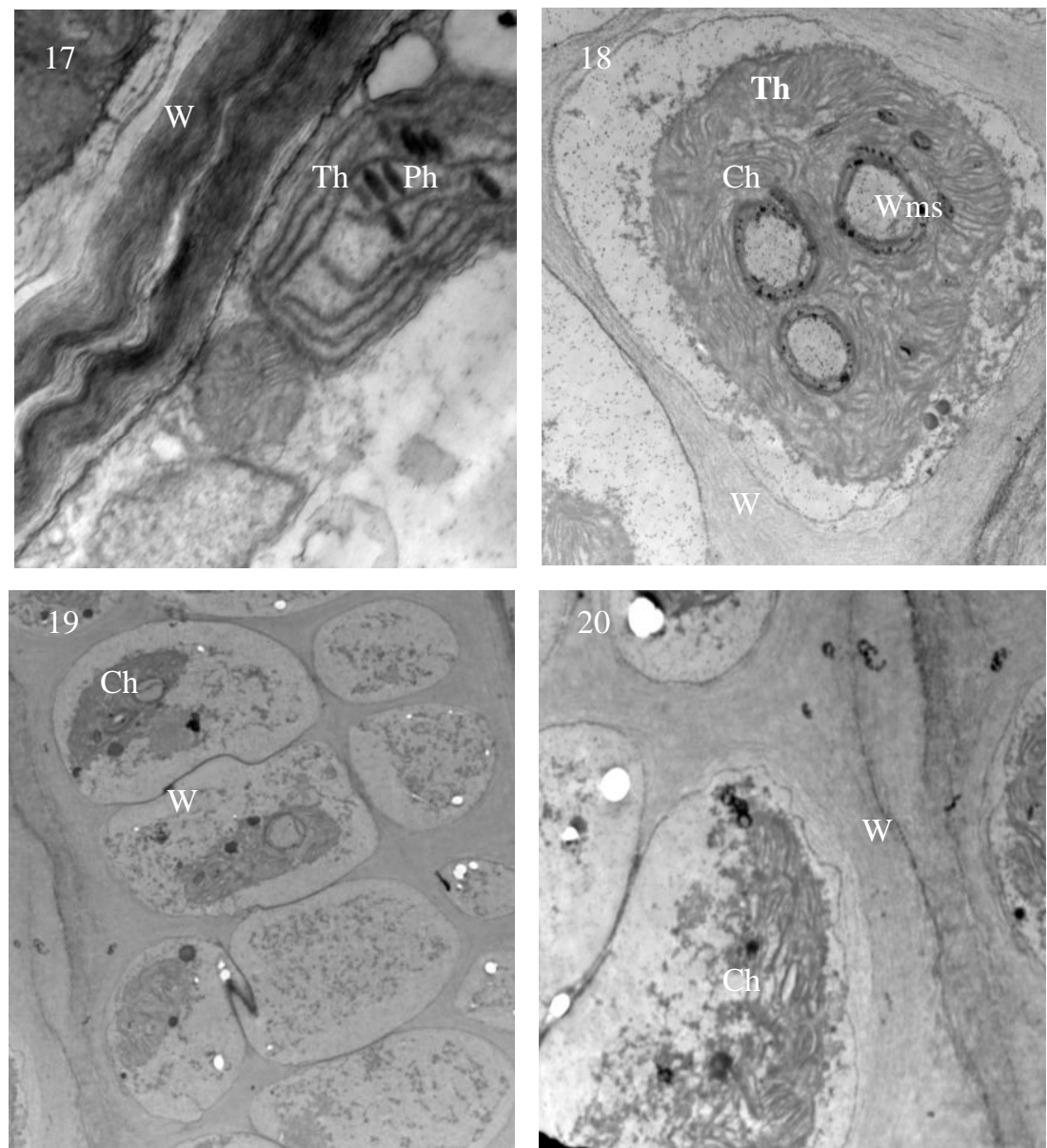

Fig. 17-20. Electron micrographs of $P$. capillacea and $U$. lactuca after exposure to different treatments. Fig.17. Pterocladia after exposure to nonylphenol. Fig.18-20. Ulva after exposure to nonylphenol. In the sections showing the chloroplast $(\mathrm{Ch})$, The cell wall (W), the thylakoids of chloroplast (Th), the whorl membrane structure (Wms) and the phycobilisomes (Ph). 

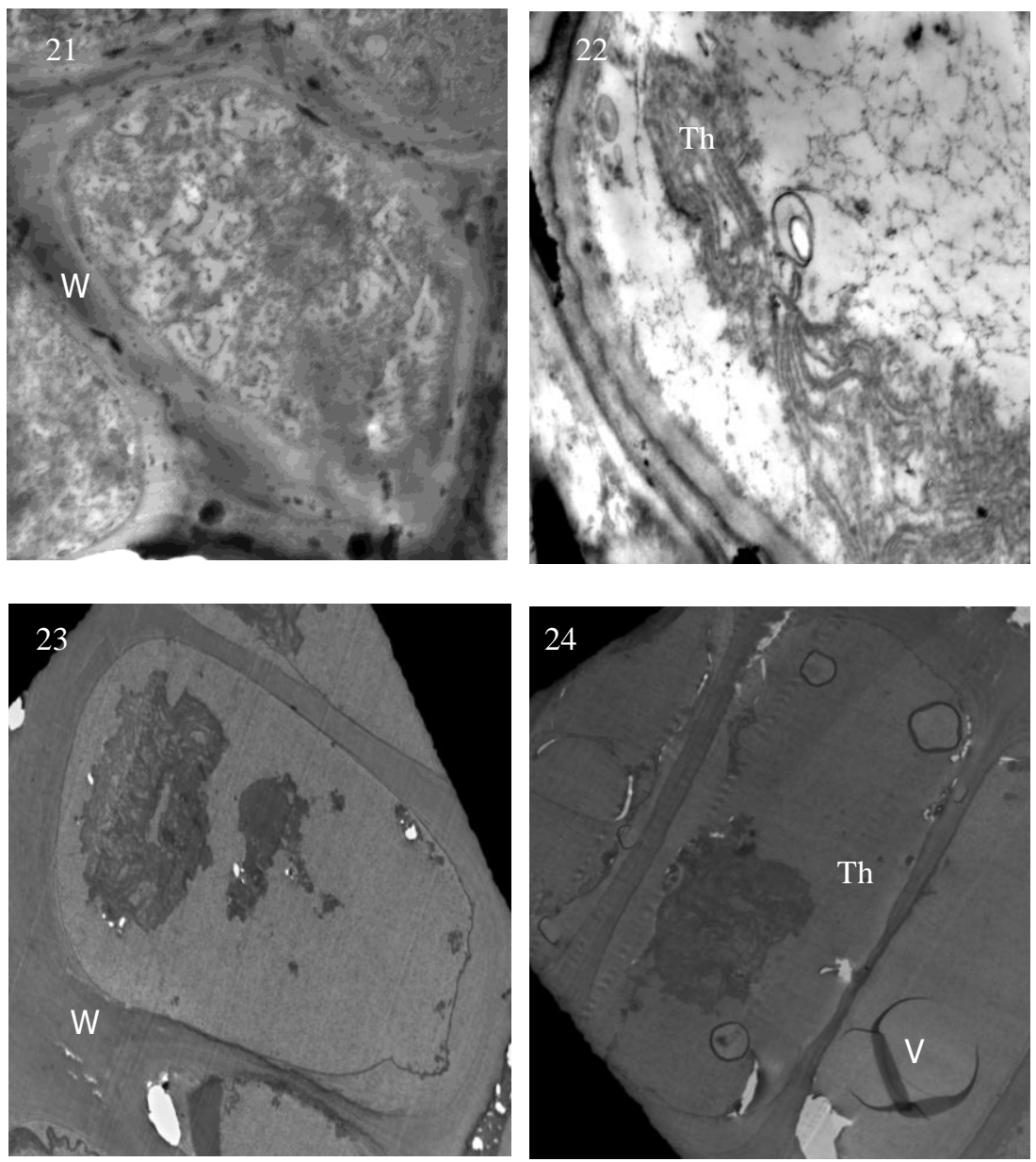

Fig.21-24. Electron micrographs of $P$. capillacea and $U$. lactuca after exposure to different treatments. Fig.21. Pterocladia after exposure to bisphenol. Fig.22. Details of chloroplast of Pterocladia after exposure to bisphenol. Fig.23\&24. Ulva after exposure to bisphenol. In the sections showing the cell wall (W), the vacuole (V) and the thylakoids of chloroplast (Th).

\section{References}

Akay, C., Deglm, I.T., Sayal, A., Aydin, A., Ozkan, Y. and Gul, H. (2008) Rapid and simultaneous determination of acetyl salicylic acid, paracetamol, and their degradation products by HPLC in pharmaceutical dosage forms. Turk J. Med. Sci., 2: 167-172.

Egypt. J. Bot., 56, No. 1 (2016) 
Arunakumara, K. and Zhang Xuecheng, (2009) The effects of heavy metals $\left(\mathrm{Pb}^{2+}\right.$ and $\mathrm{Cd}^{2+}$ ) on the ultrastructure and pigment contents of the unicellular cyanobacterium Synechocystis sp. Chin. J. Oceano. Limno., 2: 383-388.

Barata, C., Navarro, J., Varo, I., Riva, M., Arun, S. and Porte, C. (2005) Changes in antioxidant enzyme activities, fatty acid composition and lipid peroxidation in Daphnia magna during the aging process. Compar. Biochem. Physiol. Part B, 140: 8 $1-90$.

Bhargava, P., Yogesh, M., Ashish, S., Kumar, Anjum, A. and Chand, R.L. (2006) Preliminary analysis of cuprome of anabaena doliolum using two-dimensional gel electrophoresis.Current Science, 91: 1521-1523.

Gattulo, C.E., Bahrs, H., Steinberg, C. and Loffredo, E. (2012) Removal of bisphenol by the fresh water green alga Monoraphidium braunii and the role of natural organic matter. Science of the Total Environment, 416: 501-506.

Gao Y and Yan X, (2012). Response of Chara globularis and Hydrodictyon reticulatum to lead pollution: their survival, bioaccumulation, and defence. J. Appl. Phycol, 24: 245-251.

Jones, O.A.H., Voulvoulis, N. and Lester, J.N. (2002) Aquatic environmental assessment of the top 25 English perception pharmaceuticals. Water Res., 36: 50135022 .

Kaplon, D. (2013) Absorption and adsorption of heavy metals by microalgae. "Applied Phycology and Biotechnology" $2^{\text {nd }}$ ed. by Amos and Qiang, Ltd.

Koplin, D.W., Furlong, E.T., Meyer, M.T., Thurman, E.M., Zaugg, S.D., Barber, L.B. and Bxton, H.T. (2002) Pharmaceuticals, hormones and other organic wastwater cotaminants in US streams, 1999-2000: a national reconnaissance. Environ. Sci. Technol., 36: 1202-1211.

Kovacevic, G., Kalafati, M., Ljube, N. and Junji, H. (2001) The effect of chloramphenicol on the symbiosis between alga and hydra. Biologia, Bratislava, 6: 605610.

Laemmli, U.K. (1970) Cleavage of Structural Proteins during the Assembly of the Head of bacteriophage T4. Nature, 227: $680-685$.

Lau-Cam, C., Theofanopoulos, V. and Spireas, S.S. (2006) Simplified HPLC method with spectophotometric detection for the assay of clofibric acid in rat plasma. Jounal of Liquid Chromatogrphy., 18/20,1995-1998.

Mooney, H.M. and Patching, J.W. (1998) Electron microscopy of the marine microalga Dunaliella tertiolecta exposed to triphenyltin. Journal of Industerial Microbiology and Biotechnology, 20: 200-204.

Mercer, E.H. and Birbeck, M.S.C. (1966) "Electron Microscopy: A Handbook for Biologists" $2^{\text {th }}$ ed, Oxford: Blackwell Scientific Publications, p.85. 
Rath, J. and Adhikary, S.P. (2007) Response of the Estuarine Cyanobacterium Lyngbya Aestuarii to UV-B Radiation. Journal of Applied Phycology, 19: 529-536.

Rajendran, U.M., Elango, K. and Anand, N. (2007) Effects of a Fungicide, an insecticide and a biopesticide on Tolypothrix scytonemoides. Pesticide biochemistry and Physiology, 87: 164-171.

Rangsayatorn, N., Upatham, E.S., Kruatrachue, M., Pokethitiyook, P. and Lanza, G.R. (2002) Phytoremediation potential of Spirulina (Arthrospira) platensis: biosorption and toxicity studies of cadmium. Environ. Pollut, 119: 45-53.

Shanab, S., Essa, A. and Shalaby, E. (2012) Bioremoval capacity of three heavy metals by some microalgae species. Plant signaling \& Behavior., 7:1-8.

Sinha, R. P., Singh, N. Kumar, A. Kumar, H. D. Häder, M. and Häder, D.P. (1996). Effects of UV Irradiation on Certain Physiological and Biochemical Processes in Cyanobacteria. Journal of Photochemistry and Photobiology Biology, 32: 107-113.

Smith -Johanson, H. and Gibbs, S. (1972) Effects of chloramphenicol on chloroplast and mitochondrial ultrastructure in Ochromonas danica. Journal of Cell Biology., 52: 598-614.

Smith-Johannsen, H. Fromson, D. and Gibbs, S. (1980) Effects of spectinomycin and ethidium bromide on the synthesis of organelle rRNAand on ultrasturcture in Ochromonas danica. J. Cell Set., 43: 119-136.

Stumpf, M., Ternes, T.A., Haberer, K., Seel, P. and Baumann, W., (1996) Nachwis von arzneimitterlruckstaden in kläranlagen and fliegewässern. Vom Wasser, 86: 291303.

Stumpf, M., Ternes, T.A., Wilken, R.D., Rodrigues, S.V. and Baumann, W. (1999) Polar drug residues in sewage and natural waters in the state of Rio de Janeiro, Brazil. Sci. Total Environ., 225: 135-141

Ternes, T.A., Stumpf, M., Schuppert, B. and Haberer, K. (1998) Simultaneous determination of antiseptics and acidic drugs in sewage and river water. Vom Wasser, 90: 295-309.

Wang, J. and Xie, P. (2007). Antioxidant enzyme activities of Microcystis aeruginosa in response to nonylphenols and degradation of nonylphenols by $M$. aeruginosa. Environ. Geochem. Health, 29: 375-383

Wang, J., Xie, P. and Guo, N. (2007) Effect of nonylphenol on the growth and microcystin production of Microcystis strains. Environmental Res. 103: 70-78.

Weber, A. and Jung, K. (2002) Profiling early osmostress-dependent gene expression in Escherichia coli Using DNA macroarrays. J. of Bacteriology, 184: 5502-5507.

Xiong, L., Wu, Z.B., Kuang, Q.J., Xia, Y. C., and He, F. (2002) Studies on the toxicity of cypermethrin to Scenedesmus obliquus. Acta Hydrobiologica Sinica, 26: 66-73 
Yoshida, N., IKeda, R. and Okuno, T. (2006) Identification and characterization of heavy metal resistant unicellular alga isolated from soil and its potential for phytoremediation, Bioresource Technol., 97: 1843-1849.

Yu, J., Yang, C., Yu, R.A. and Fu, G. (2007) Toxic response of dimethyl phthalate (DMP) to Gracilaria lemaneiformis. Electronic Journal of Biology, 3: 80-8

Zuccato, E., Calamari, D., Natangelo, M. and Fanelli, R. (2000) Presence of therapeutic drugs in the environment. The Lancelot, 35: 1789-1790.

\title{
تأثير بعض المركبات الصيدلانية على التفريغ الكهربي للبروتين

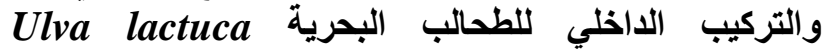 \\ Pterocladia capillareas
}

\author{
سعاد محمل محي الدين ونادية حجازي نعمان وسهام حسني زكي

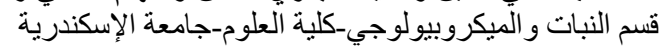 \\ إن التلوث العضوي هو قضية بارزة في العالم، ومن المهم أن نكثف عن آثار هذه

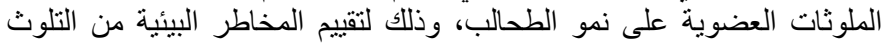 \\ العضوي، حيث تم اختبار بعض المض الملوثات مثل \\ Clofibric acid و salicylic acid Acetyl, Chloramphenicol \\ Bisphenol gNonylphenol و \\ على اختبار التفريغ الكهربي للبروتين كأداة تحليلية لتعزل وتحديد البروتين في

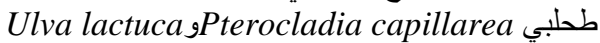 \\ وكذلك دراسة تأثير تلك الملوثات على التركيب الداخلي لكل من خلايا الطحلبين

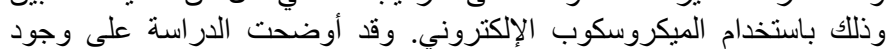

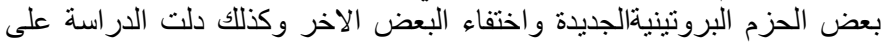

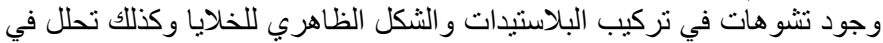

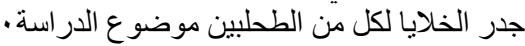

